\title{
Metallized Gelled Propellants Combustion Experiments in a Pulse Detonation Engine
}

Bryan Palaszewski

Glenn Research Center, Cleveland, Ohio

John Jurns

QSS Group, Inc., Cleveland, Ohio

Kevin Breisacher and Kim Kearns

Glenn Research Center, Cleveland, Ohio 


\section{NASA STI Program . . . in Profile}

Since its founding, NASA has been dedicated to the advancement of aeronautics and space science. The NASA Scientific and Technical Information (STI) program plays a key part in helping NASA maintain this important role.

The NASA STI Program operates under the auspices of the Agency Chief Information Officer. It collects, organizes, provides for archiving, and disseminates NASA's STI. The NASA STI program provides access to the NASA Aeronautics and Space Database and its public interface, the NASA Technical Reports Server, thus providing one of the largest collections of aeronautical and space science STI in the world. Results are published in both non-NASA channels and by NASA in the NASA STI Report Series, which includes the following report types:

- TECHNICAL PUBLICATION. Reports of completed research or a major significant phase of research that present the results of NASA programs and include extensive data or theoretical analysis. Includes compilations of significant scientific and technical data and information deemed to be of continuing reference value. NASA counterpart of peer-reviewed formal professional papers but has less stringent limitations on manuscript length and extent of graphic presentations.

- TECHNICAL MEMORANDUM. Scientific and technical findings that are preliminary or of specialized interest, e.g., quick release reports, working papers, and bibliographies that contain minimal annotation. Does not contain extensive analysis.

- CONTRACTOR REPORT. Scientific and technical findings by NASA-sponsored contractors and grantees.
- CONFERENCE PUBLICATION. Collected papers from scientific and technical conferences, symposia, seminars, or other meetings sponsored or cosponsored by NASA.

- SPECIAL PUBLICATION. Scientific, technical, or historical information from NASA programs, projects, and missions, often concerned with subjects having substantial public interest.

- TECHNICAL TRANSLATION. Englishlanguage translations of foreign scientific and technical material pertinent to NASA's mission.

Specialized services also include creating custom thesauri, building customized databases, organizing and publishing research results.

For more information about the NASA STI program, see the following:

- Access the NASA STI program home page at http://www.sti.nasa.gov

- E-mail your question via the Internet to help@sti.nasa.gov

- Fax your question to the NASA STI Help Desk at 301-621-0134

- Telephone the NASA STI Help Desk at 301-621-0390

- Write to:

NASA STI Help Desk

NASA Center for AeroSpace Information 7121 Standard Drive Hanover, MD 21076-1320 


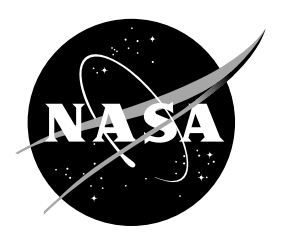

\section{Metallized Gelled Propellants Combustion Experiments in a Pulse Detonation Engine}

Bryan Palaszewski

Glenn Research Center, Cleveland, Ohio

John Jurns

QSS Group, Inc., Cleveland, Ohio

Kevin Breisacher and Kim Kearns

Glenn Research Center, Cleveland, Ohio

Prepared for the

40th Joint Propulsion Conference and Exhibit

cosponsored by AIAA, ASME, SAE, and ASEE

Fort Lauderdale, Florida, July 11-14, 2004

National Aeronautics and

Space Administration

Glenn Research Center

Cleveland, Ohio 44135 


\section{Acknowledgments}

We would like to acknowledge the Revolutionary Aeropropulsion Concepts (RAC) Project and the Low Emissions Alternative Power (LEAP) Project at NASA Glenn Research Center for providing the funding for this work.

This work was sponsored by the Low Emissions Alternative

Power Project of the Vehicle Systems Program at the NASA Glenn Research Center.

Level of Review: This material has been technically reviewed by technical management.

Available from

NASA Center for Aerospace Information 7121 Standard Drive

Hanover, MD 21076-1320
National Technical Information Service 5285 Port Royal Road Springfield, VA 22161 


\title{
Metallized Gelled Propellants Combustion Experiments in a Pulse Detonation Engine
}

\author{
Bryan Palaszewski \\ National Aeronautics and Space Administration \\ Glenn Research Center \\ Cleveland, Ohio 44135 \\ John Jurns \\ QSS Group, Inc. \\ Cleveland, Ohio 44135 \\ Kevin Breisacher and Kim Kearns \\ National Aeronautics and Space Administration \\ Glenn Research Center \\ Cleveland, Ohio 44135
}

\begin{abstract}
A series of combustion tests were performed with metallized gelled JP-8/aluminum fuels in a Pulse Detonation Engine (PDE). Nanoparticles of aluminum were used in the 60 to 100 nanometer diameter. Gellants were also of a nanoparticulate type composed of hydrocarbon alkoxide materials. Using simulated air (a nitrogen-oxygen mixture), the ignition potential of metallized gelled fuels with nanoparticle aluminum was investigated. Ignition of the JP-8/aluminum was possible with less than or equal to a $23-\mathrm{wt} \%$ oxygen loading in the simulated air. JP-8 fuel alone was unable to ignite with less than 30 percent oxygen loaded simulated air. The tests were single shot tests of the metallized gelled fuel to demonstrate the capability of the fuel to improve fuel detonability. The tests were conducted at ambient temperatures and with maximal detonation pressures of 1340 psia.
\end{abstract}

\section{Nomenclature}

$\begin{array}{ll}\text { Al } & \text { Aluminum } \\ \text { CEA } & \text { Chemical Equilibrium Compositions and Applications } \\ \text { CVCCE } & \text { Constant Volume Combustion Cycle Engine } \\ \text { JP-8 } & \text { Jet Propellant } 8 \\ \text { LOA-L } & \text { Lock on After Launch } \\ \text { LOB-L } & \text { Lock on Before Launch } \\ \text { ML } & \text { Metal loading } \\ \text { NAS } & \text { National Academy of Sciences } \\ \text { NRC } & \text { National Research Council } \\ \text { N }_{2} & \text { Nitrogen } \\ \text { PDE } & \text { Pulse detonation engine } \\ \text { RAC } & \text { Revolutionary Aeropropulsion Concept } \\ \text { RCL } & \text { Research Combustion Laboratory } \\ \text { Isp } & \text { Specific impulse (seconds) } \\ \text { TEM } & \text { Transmission electron microscopy } \\ \text { TOF } & \text { Time of flight } \\ \text { wt } \% & \text { Weight percent }\end{array}$




\section{Introduction}

Experimental tests were conducted with a pulse detonation engine using metallized gelled propellants. It was theorized that the addition of the metal particles would increase the energy of the fuel and also potentially increase the laminar flame speed of the detonating mixture of air and fuel. Experiments were designed to investigate the performance, ignition, and detonation characteristics of JP-8/aluminum metallized gelled fuels in an airbreathing pulse detonation engine.

The NASA Glenn Research Center is currently investigating hybrid Constant Volume Combustion Cycle Engine (CVCCE) concepts in which detonative (or near detonative) combustion replaces constant pressure combustion. Figure 1 illustrates method of using the PDE in a gas turbine and a supersonic to hypersonic engine. When utilized in a hybrid gas turbine engine, pulse detonation combustors have the potential of significantly increasing fuel efficiency due to their higher thermodynamic efficiency relative to conventional, near constant pressure combustors. However, the use of a pulse detonation combustor in a gas turbine engine poses numerous technical challenges including combustor/turbine compatibility and combustor cooling and durability issues. Reliably detonating a jet engine fuel at hundreds of cycles per second, efficiently, in a compact device is a major technical challenge in itself. The combustor system must also meet the additional constraints imposed by the emissions of nitrogen oxides and particulates.

As part of the Revolutionary Aeropropulsion Concept (RAC) Project, considerable efforts were made to explore the use of nanoparticulate, metal based fuels for aerospace applications. Unfortunately, due to

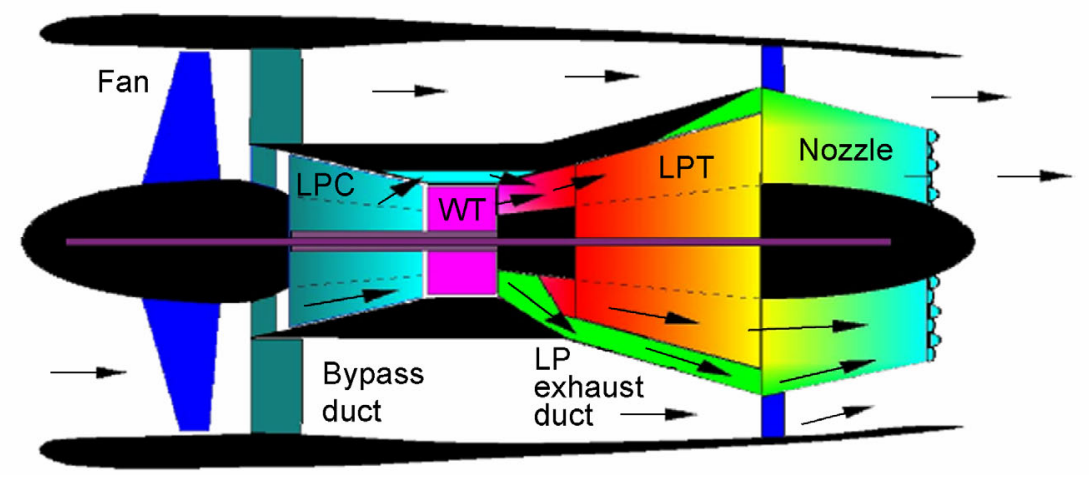

PDE Hybrid - Detonative Wave Turbine

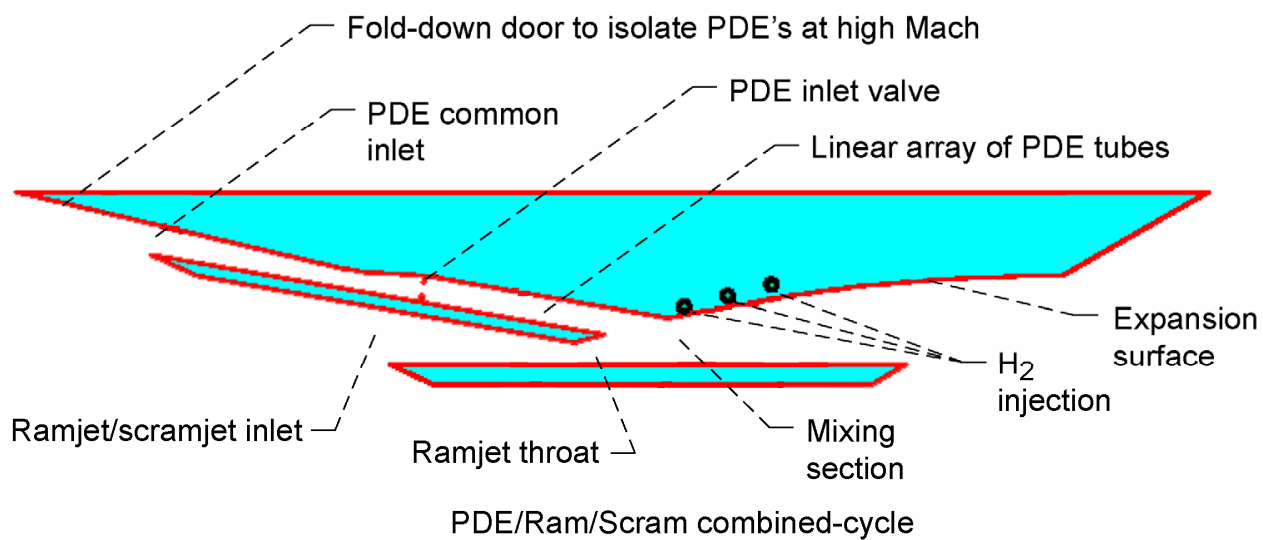

Figure 1.-PDE applications (ref. 22). 
the termination of the RAC project, it looked like the opportunity to test these propellants in a relevant combustion environment might be missed. It was decided that a brief test program (of approximately two weeks duration) utilizing existing CVCCE rig hardware might be beneficial to both the RAC and CVCCE programs. From a technical standpoint, metallized fuels provided the CVCCE program with a risk reduction strategy, if detonating neat jet fuels at gas turbine operating conditions proved too difficult. It was envisioned that a puff of metallized fuel injected in the spark region might release sufficient energy upon combusting to greatly aid the transition to detonation process.

\section{Why Metallized Gelled Propellants?}

Metallized gelled propellants have been investigated experimentally and theoretically for many years. The density increases allowed by adding metal particles to gelled liquid fuels have been analyzed for many space and aerospace missions (refs. 1 to 17). Also, these fuels can improve safety by reducing the radius of accidental fuel spills, increase the payload capacity of the vehicle, and reduce the fuel slosh typical of maneuvering aerospace vehicles. With gelled propellants, the engine can be throttled, allowing longer range flight missions than solid rocket powered vehicles. Figure 2 shows the application of gelled fuels for military missiles (ref. 17). The added range is possible by pulsing the engine on a winged vehicle, or by using a highly efficient gas turbine engine for cruise during a major portion of the flight. For higher acceleration toward the target near the end of the mission, a metallized gelled propellant rocket engine would be reignited for the final part of the mission. Appendix A shows the increases in density allowed with metallized gelled fuels. For a $16 \mathrm{wt} \%$ metal loading, the JP-8/aluminum density was increased by 12 to 13 percent. At a 60 -wt \% metal loading, the density would be increased 70 to 75 percent. Such high density increases can significantly reduce the vehicle size over the nonmetallized gelled cases and allow for improved vehicle packaging

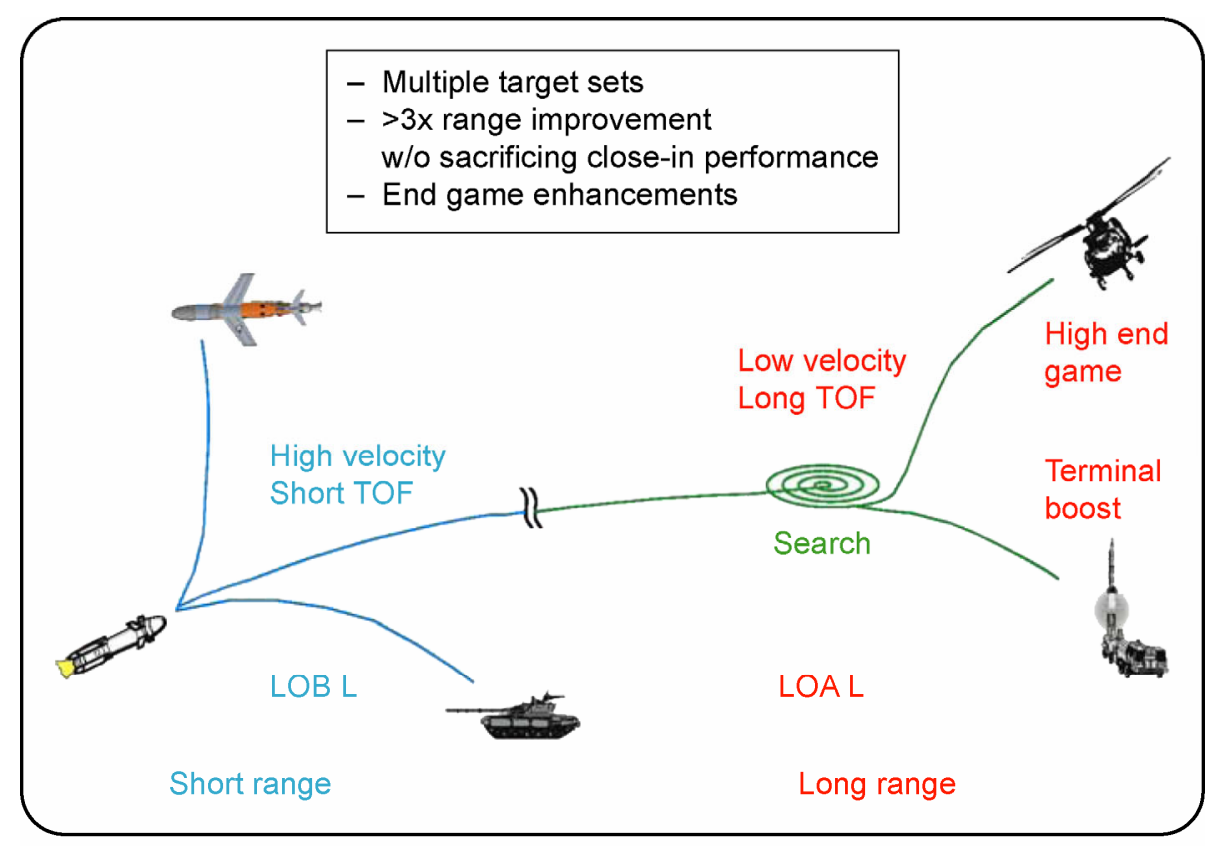

Figure 2.-Metallized gelled fuel applications: missiles (ref. 17). 


\section{Why PDEs?}

A pulse detonation engine may be a good candidate for subsonic or transonic airbreathing vehicles (ref. 18 to 29). Figure 3 shows the typical cycle elements for the PDE (ref. 23). Testing and analyses conducted by many organizations have tried to determine the best application for PDEs. Recent studies have both shown promise for its application in military systems, and some recent work has suggested that it may be useful for civilian aircraft. In some cases, detonation noise concerns may be a stumbling block for this application (ref. 18). Recent work (refs. 19 and 20) illustrated in figure 4 has shown the importance of supercharging or placing a compressor in front of the PDE for improved performance, and overall the best velocity regime may be in the high subsonic, transonic, and low supersonic range.
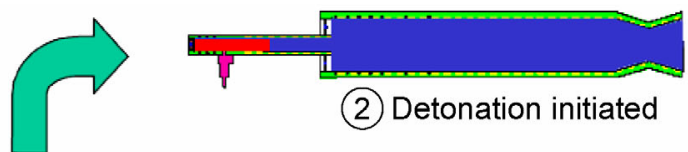

(2) Detonation initiated

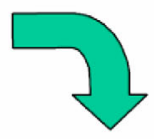

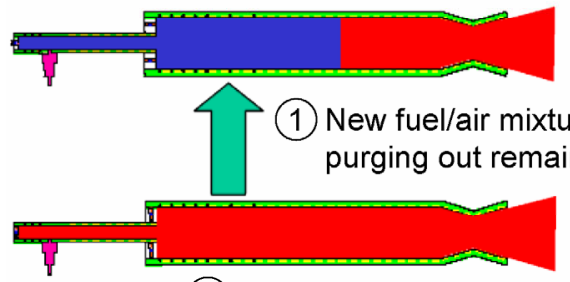

(5) Tube blows down to ambient pressure

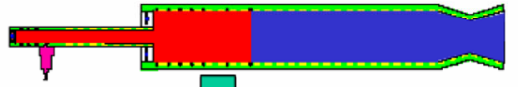

(3) Detonation transitions into main tube
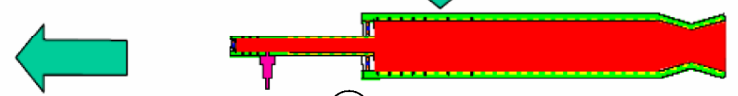

(4) Detonation propagates through length of main tube

Figure 3.-PDE cycle numbering system, 1 through 5 (ref. 28).

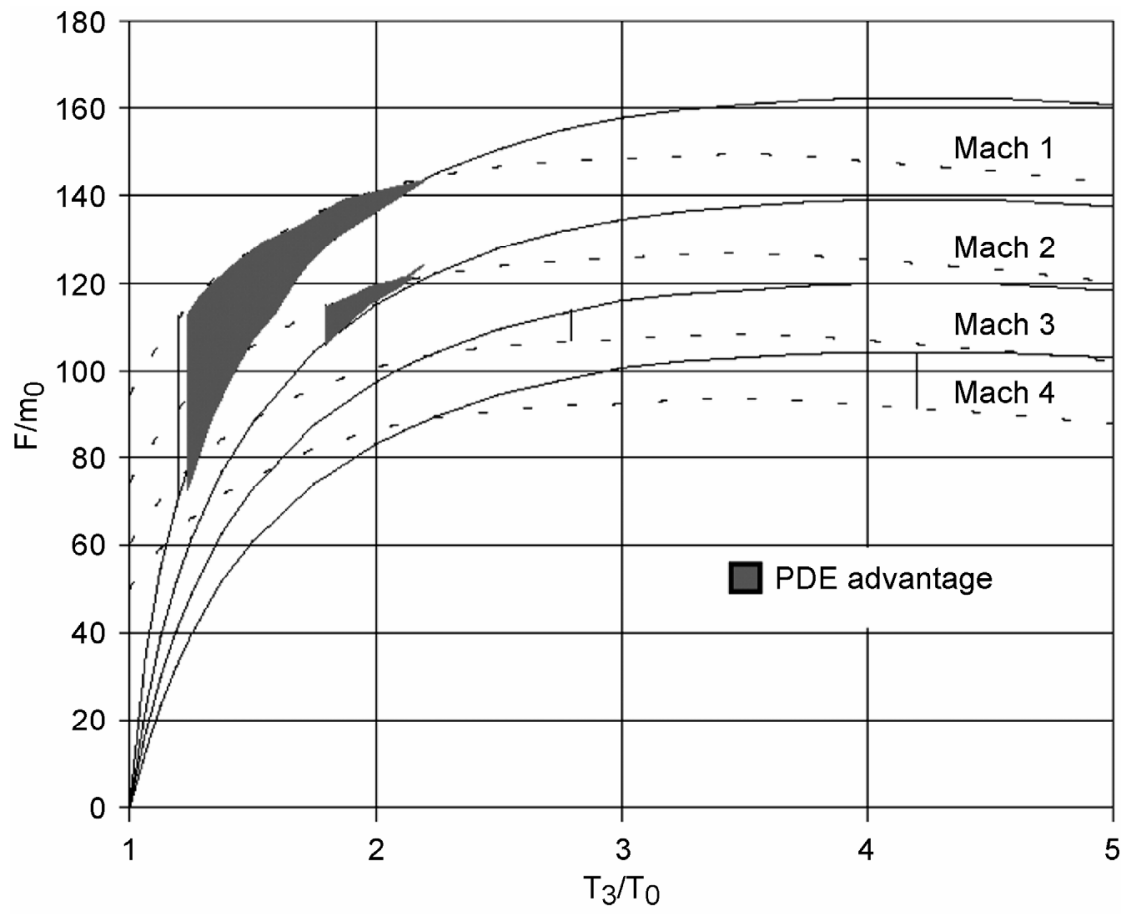

Figure 4.-PDE speed regimes and potential areas of advantage (ref. 20). 


\section{PDE Applications}

Engine designs for PDEs have been analyzed for several low speed and high speed applications (refs. 18 to 29). Figure 1 illustrates two PDE Applications (ref. 22). Using it in a gas turbine engine may reduce the complexity of the engine combustor. Using it in the low speed part of a supersonic vehicle may increase the efficiency at speed below Mach 2 (refs. 19 to 29). Many design studies have show advantages of PDEs with high speed aircraft (ref. 26). More recent thermodynamic studies have illustrated the most useful applications and the related velocity regimes. Using the PDE in subsonic and low supersonic regimes offers the best use (refs. 19 and 20).

\section{Metallized Gelled Propellants and PDEs}

Adding metal particles to the combusting flow was thought to allow a higher laminar flame speed and increase the energy of the combustion process. Experiments were planned to test this theory. Often with metallized gelled fuels, there is a 2 phase flow loss that reduces the specific impulse (Isp) performance of the fuel over the theoretical maximum performance. However, with the use of nanoengineered particles, it is thought that the 2-phase flow losses in the engine exhaust would be reduced.

\section{Fuel Formulation}

Several fuel formulations were created with $4.9,8,12,16$, and $25 \mathrm{wt} \%$ of aluminum particles in the gelled fuel. The particles were nanometer sized (60 to $100 \mathrm{~nm}$ diameter) and created with an aluminum vaporization process (ref. 30). A nanoengineered gellant material was used (refs. 2 and 3). A surfactant, Tween 85, was used to assure better dispersion of the gellant in the gelled fuel (ref. 8). Table I shows the different metallized gelled fuel formulations. Our initial selection for testing was a $5-\mathrm{wt} \%$ loading of aluminum in the JP-8/aluminum. As testing proceeded, we created other propellant formulations, and noted the reduction of added oxygen for the fuel tests with increasingly higher aluminum loadings.

TABLE 1.-METALLIZED GELLED JP-8/ALUMINUM FUEL FORMULATIONS

\begin{tabular}{|c|c|c|c|c|c|c|c|c|}
\hline Inventory No. & \multicolumn{2}{|c|}{ can \#8 } & \multicolumn{2}{|c|}{ can \#9 } & \multicolumn{2}{|c|}{ can \#10 } & \multicolumn{2}{|c|}{ can \#11 } \\
\hline Batch & \multicolumn{2}{|c|}{$4.86 \% \mathrm{Al}$} & \multicolumn{2}{|c|}{$4.86 \% \mathrm{Al}$} & \multicolumn{2}{|c|}{$4.85 \% \mathrm{Al}$} & \multicolumn{2}{|c|}{$5.03 \% \mathrm{Al}$} \\
\hline Comments & \multicolumn{2}{|c|}{$1 \mathrm{pt} \mathrm{can}$} & \multicolumn{2}{|c|}{1 pt can } & \multicolumn{2}{|c|}{$1 \mathrm{pt} \mathrm{can}$} & \multicolumn{2}{|c|}{ 1 Qt can } \\
\hline Fuel (g) & JP-8 & 250.06 & $\mathrm{JP}-8$ & 250.16 & JP-8 & 250.48 & $\mathrm{JP}-8$ & 250.06 \\
\hline Aluminum (g) & \begin{tabular}{|l} 
Technanogy \\
$60-100 \mathrm{~nm}$ \\
can $1 / 2$
\end{tabular} & 13.26 & $\begin{array}{l}\text { Technanogy } \\
60-100 \mathrm{~nm} \\
\text { can } 1 / 2\end{array}$ & 13.27 & $\begin{array}{l}\text { Technanogy } \\
60-100 \mathrm{~nm} \\
\text { can } 1 / 2\end{array}$ & 13.25 & $\begin{array}{l}\text { Technanogy } \\
60-100 \mathrm{~nm} \\
\text { can } 1 / 2\end{array}$ & 13.58 \\
\hline Gellant (g) & $\begin{array}{l}\text { TRW } \\
\text { Aerogel } \\
32808-29\end{array}$ & 6.62 & $\begin{array}{l}\text { TRW } \\
\text { Aerogel } \\
32808-29+ \\
32808-37\end{array}$ & 6.59 & \begin{tabular}{|l} 
TRW \\
Aerogel \\
$32808-29+$ \\
$32808-37$
\end{tabular} & 6.44 & $\begin{array}{l}\text { TRW Aerogel } \\
32808-34\end{array}$ & 3.3 \\
\hline Surfactant (g) & Tween 85 & 3.18 & Tween 85 & 3.23 & Tween 85 & 3.2 & Tween 85 & 3.2 \\
\hline$\%$ Fuel & & $91.56 \%$ & & $91.55 \%$ & & $91.63 \%$ & & $92.57 \%$ \\
\hline$\% \mathrm{Al}$ & & $4.86 \%$ & & $4.86 \%$ & & $4.85 \%$ & & $5.03 \%$ \\
\hline$\%$ Gellant & & $2.42 \%$ & & $2.41 \%$ & & $2.36 \%$ & & $1.22 \%$ \\
\hline$\%$ Surfactant & & $1.16 \%$ & & $1.18 \%$ & & $1.17 \%$ & & $1.18 \%$ \\
\hline Mixing & Sonicator & & Sonicator & & Sonicator & & Sonicator & \\
\hline Viscosity & $\mathrm{X}$ & & & & & & $\mathrm{X}$ & \\
\hline PDE Combustion & $\mathrm{X}$ & & $\mathrm{X}$ & & $\mathrm{X}$ & & $\mathrm{X}$ & \\
\hline
\end{tabular}


TABLE 1.-(Continued)

\begin{tabular}{|c|c|c|c|c|c|c|c|c|}
\hline Inventory No. & \multicolumn{2}{|c|}{ can \#12 } & \multicolumn{2}{|c|}{ can \#13 } & \multicolumn{2}{|c|}{ can \#14 } & \multicolumn{2}{|c|}{ can \#15 } \\
\hline Batch & \multicolumn{2}{|c|}{$12 \% \mathrm{Al}$} & \multirow{2}{*}{\multicolumn{2}{|c|}{$8.01 \% \mathrm{Al}$}} & \multirow{2}{*}{\multicolumn{2}{|c|}{$24.68 \% \mathrm{Al}$}} & \multicolumn{2}{|c|}{$15.99 \% \mathrm{Al}$} \\
\hline Comments & \multicolumn{2}{|c|}{ 1 Qt can } & & & & & \multicolumn{2}{|c|}{$1 \mathrm{pt}$ can } \\
\hline Fuel (g) & JP-8 & 248.58 & $\mathrm{JP}-8$ & 248.17 & JP-8 & 248.63 & JP-8 & 250.01 \\
\hline Aluminum (g) & $\begin{array}{l}\text { Technanogy } \\
60-100 \mathrm{~nm} \\
\text { can } 1 / 2\end{array}$ & 34.79 & $\begin{array}{l}\text { Technanogy } \\
60-100 \mathrm{~nm} \\
\text { can } 1 / 2 \\
\end{array}$ & 22.17 & \begin{tabular}{|l} 
Technanogy \\
$60-100 \mathrm{~nm}$ \\
can $1 / 2$ \\
\end{tabular} & 83.58 & $\begin{array}{l}\text { Technanogy } \\
60-100 \mathrm{~nm} \\
\text { can } 1 / 2\end{array}$ & 48.74 \\
\hline Gellant (g) & $\begin{array}{l}\text { TRW } \\
\text { Aerogel } \\
32808-34\end{array}$ & 3.28 & \begin{tabular}{|l|} 
TRW \\
Aerogel \\
$32808-34$
\end{tabular} & 3.28 & $\begin{array}{l}\text { TRW } \\
\text { Aerogel } \\
32808-34\end{array}$ & 3.28 & $\begin{array}{l}\text { TRW Aerogel } \\
32808-17\end{array}$ & 3.06 \\
\hline Surfactant (g) & Tween 85 & 3.2 & Tween 85 & 3.2 & Tween 85 & 3.23 & Tween 85 & 3.009 \\
\hline$\%$ Fuel & & $85.76 \%$ & & $89.65 \%$ & & $73.40 \%$ & & $82.02 \%$ \\
\hline$\% \mathrm{Al}$ & & $12.00 \%$ & & $8.01 \%$ & & $24.68 \%$ & & $15.99 \%$ \\
\hline$\%$ Gellant & & $1.13 \%$ & & $1.18 \%$ & & $0.97 \%$ & & $1.00 \%$ \\
\hline$\%$ Surfactant & & $1.10 \%$ & & $1.16 \%$ & & $0.95 \%$ & & $0.99 \%$ \\
\hline Mixing & Sonicator & & Sonicator & & Sonicator & & Sonicator & \\
\hline Viscosity & $\mathrm{X}$ & & $\mathrm{X}$ & & $\mathrm{X}$ & & $\mathrm{X}$ & \\
\hline PDE Combustion & $\mathrm{X}$ & & $\bar{X}$ & & $\bar{X}$ & & $\bar{X}$ & \\
\hline
\end{tabular}

\section{A. Fuel Selection and Formulation}

The primary liquid fuel selected was JP-8 (ref. 31). This fuel was selected as it is typically used in designed for future high energy missiles and is planned for future high speed aircraft. Based on past rocket experience, other options that were considered but not pursued were RP-1/aluminum formulations. As JP-8 and RP-1 were sufficiently similar in physical characteristics, only one base fuel option was tested.

Aluminum additives were selected as a typical additive based on past historical selection criteria for performance and for their relative ease of handling. Aluminum particles in the 60 to 100 nanometer diameter range were obtained from Technanogy, LLC (ref. 32) and used in all of the formulations.

\section{B. Aluminum Particles and Gellants}

Figures 5 through 7 shows a set of typical transmission electron microscopy (TEM) photomicrograph of the nanometer sized aluminum particles. Figure 5 gives an overview with many particles and it shows a lacy structure between the many particles. This lacy material was part of the standard sample holder used to hold the particles while being analyzed and imaged in the TEM machine (ref. 33). Figure 6 shows a close up of several particles. Figure 7 shows a close up of the edge of the aluminum oxide layer that coats the particle. Based on the imaging, the particles were confirmed to be approximately 60 to $100 \mathrm{~nm}$ in diameter.

The thickness of the oxide layer is quite important in determining the fuel additive energy potential. With a $100 \mathrm{~nm}$ particle, the amount of aluminum in the particle can be as high as 70 to 80 percent. This is based on the particle oxide layer being $2.5 \mathrm{~nm}$ thick. As the particles become smaller, the fraction of Al goes down to about 40 to 50 percent in a $20 \mathrm{~nm}$ particle. Thus, the 60 to $100 \mathrm{~nm}$ diameter particles were used for the initial PDE testing. The breakup of the aluminum oxide coating in an aluminum combustion process is discussed in references 34 and 35 .

Gellants were selected on the basis of past testing. Nanoengineered gellants from TRW (now Northup Grumman Space Technology) were hydrocarbon alkoxide materials created with a sol gel process (refs. 2 and 3). These gellants were formulated to reduce the total mass of gellant needed for effective gelation and the gellant has a surface area of approximately 800 to $900 \mathrm{~m}^{2} / \mathrm{g}$ (refs. 2 and 3). This surface area is 2 to 3 times higher than completing particulate $\mathrm{SiO}_{2}$ gellants (refs. 2 and 3). 


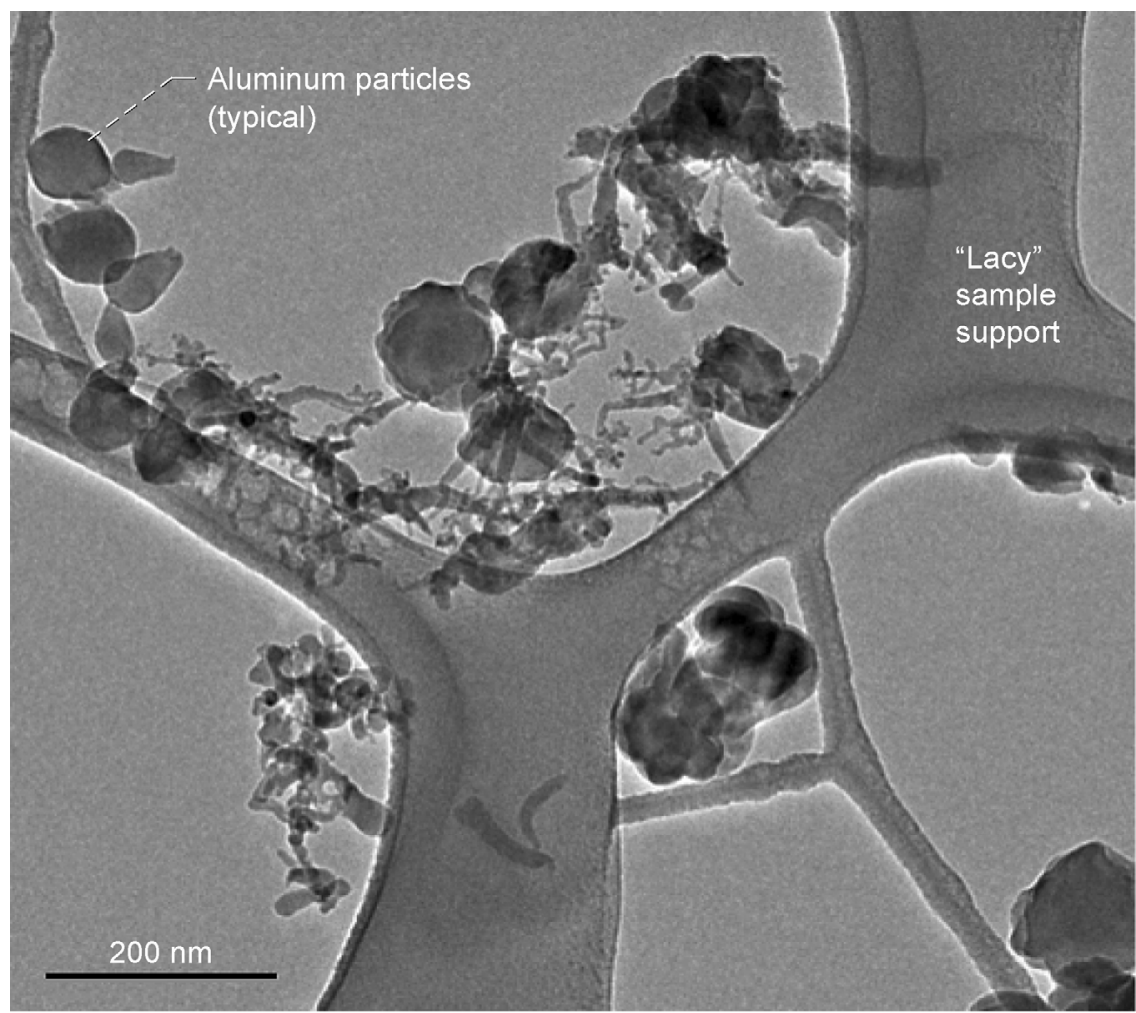

Figure 5.-TEM photograph of 60 to 100 nanometer diameter aluminum particles on "lacy" TEM imaging sample support.

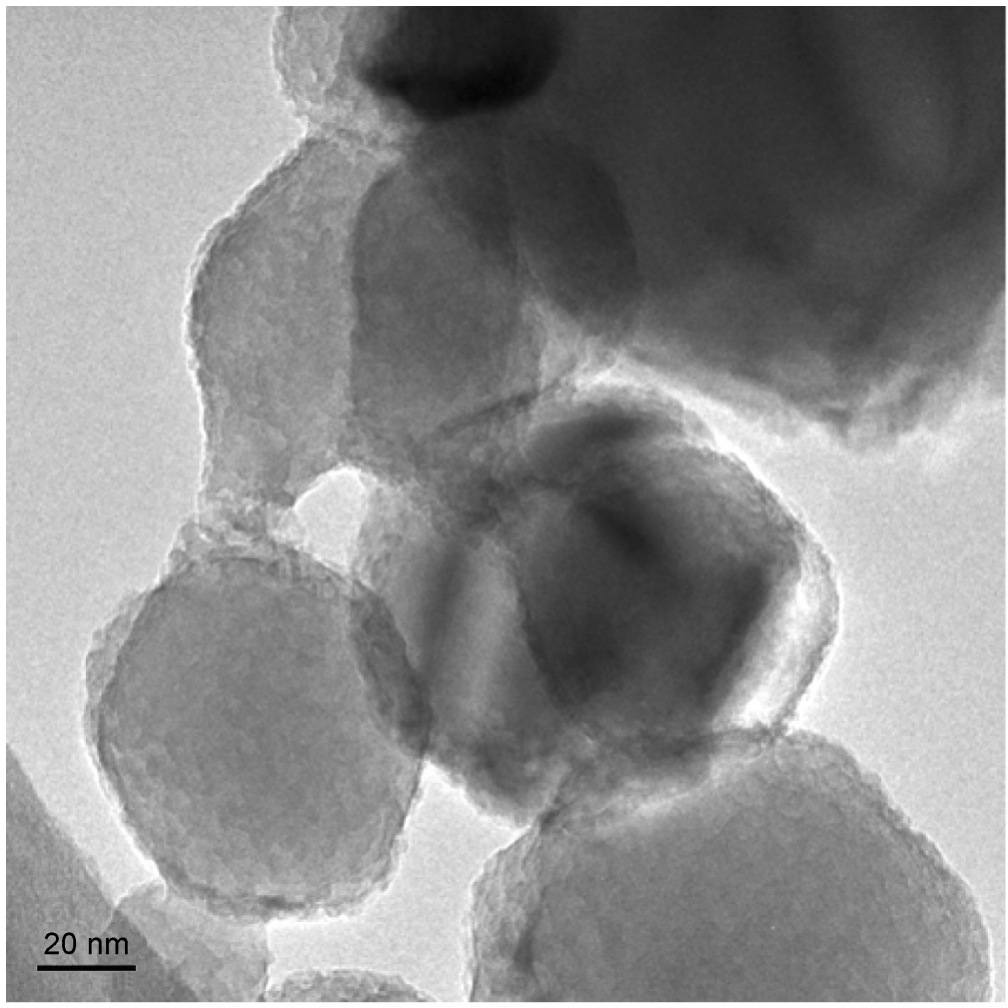

Figure 6.-TEM photograph of 60 to 100 nanometer diameter aluminum particles (closeup). 


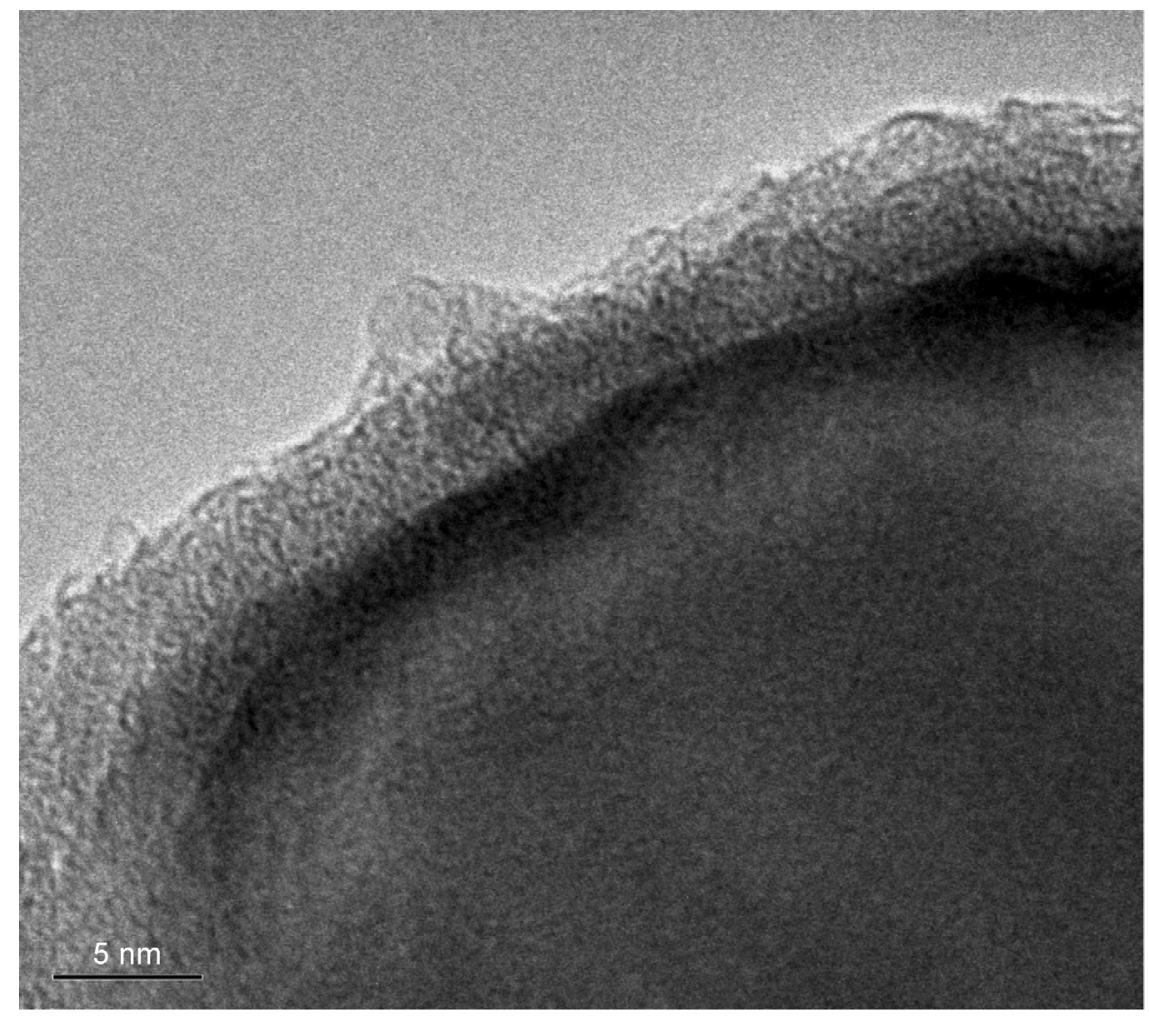

Figure 7.-TEM photograph of 60 to 100 nanometer diameter aluminum particle aluminum oxide layer (closeup).

The fuel was formulated in the Research Combustion Laboratory (RCL) Cell 11 of the NASA Glenn Research Combustion Laboratory (RCL). Using a glove bag, the components of the fuel were mixed in controlled amounts using a precision electronic scale. Nitrogen inerting was used in the glove bag to prevent water exposure to the nanometer size aluminum particles. Care must be taken to prevent ignition of the particles with exposure to water vapor in the air. Once the particles are mixed in the fuel, the ignition problems are more benign.

After mixing of the metal particles, gellant, liquid fuel, and surfactant, the mixture was subjected to ultrasonic mixing (with a sonicator). The fuel components were mixed in a small pint quantity containers with an ultrasonic probe protruding into the metallized gelled fuel. This mixing was conducted for up to 15 minutes. Temperatures of the metallized gelled fuel were monitored with a thermocouple in the mixing vessel. Mixing was slowed if the temperature of the fuel or tank locally exceeded $200^{\circ} \mathrm{F}$.

\section{Experimental Setup: Pulse Detonation Engine Test Hardware}

The PDE was tested in Cell 21 of the Research Combustion Laboratory (RCL) at NASA Glenn Research Center (ref. 36). Figure 8 shows the general cell configuration with 2 test stands. The metallized gelled fuel PDE tests were conducted in September 2003. Figure 9 shows the overall PDE engine schematic. The engine is a modular design that can be as long a 6 feet. Various injectors and igniters can be used with the engine. Location of the igniters can be varied as well.

Testing was conducted with an initial metal loading of $5 \mathrm{wt} \%$ aluminum. It was selected as it delivers the highest value of rocket specific impulse for $\mathrm{O}_{2} / \mathrm{RP}-1 /$ aluminum (refs. 9 and 11). Later analyses were conducted with detonation simulation software (ref. 37, CEA code), and additional metal loadings up to $25 \mathrm{wt} \%$ were tested. 


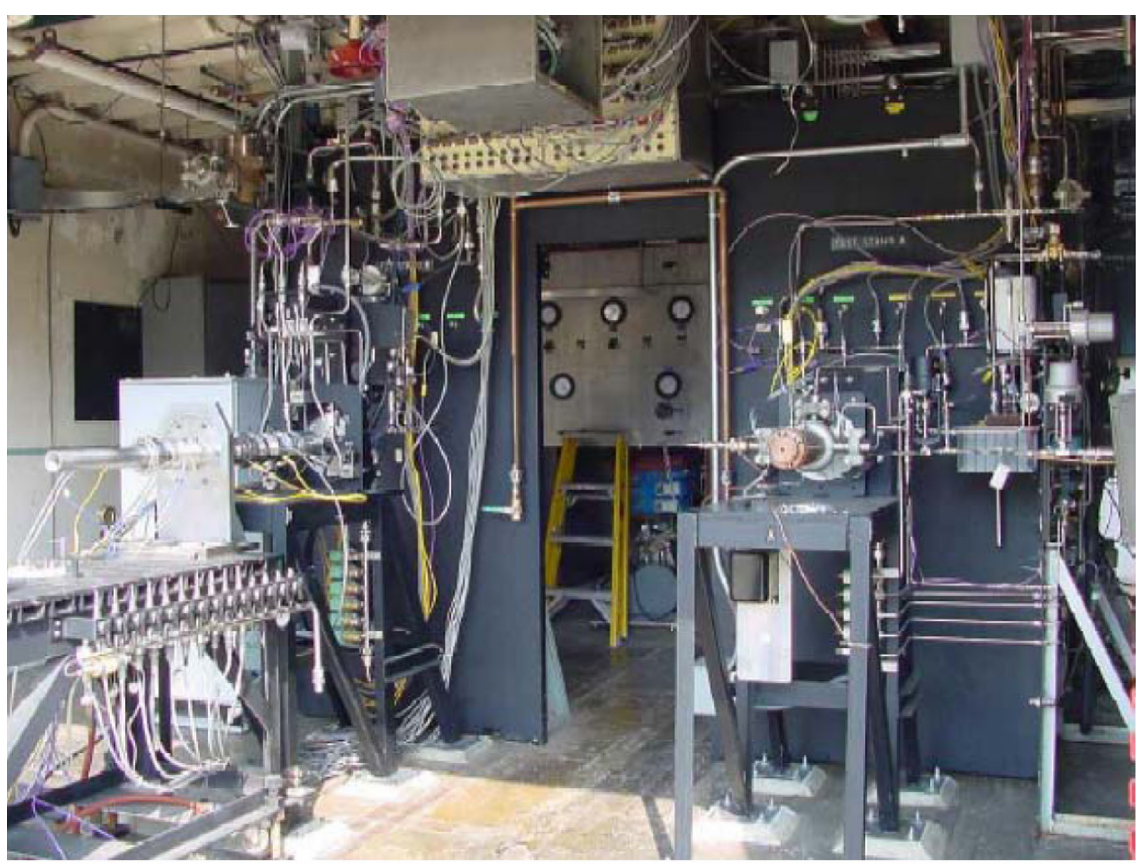

Figure 8.-RCL cell 21 test cell.

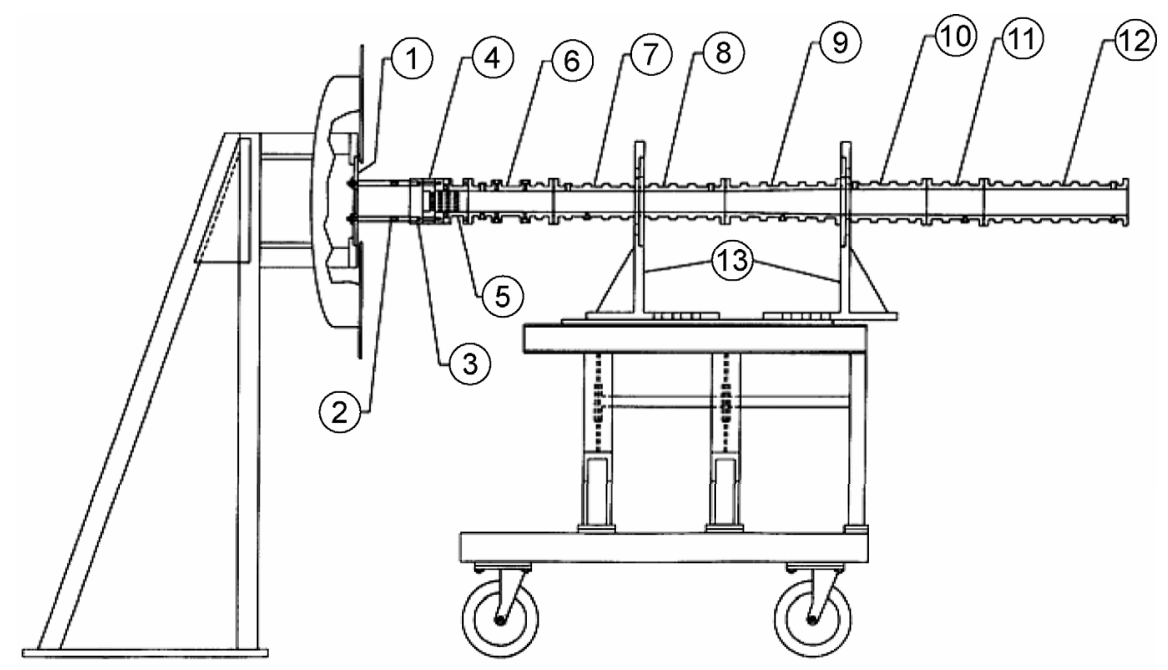

Figure 9.-PDE schematic.

The metallized gelled JP-8 PDE testing was conducted in Cell 21 of the Research Combustion Laboratory (RCL, ref. 36) at NASA Glenn Research Center on the CVCCE Testbed. The CVCCE Testbed, shown in figures 10 through 13 , was designed to be a highly modular rig to accommodate a variety of experimental configurations for investigating detonative phenomena. The inner diameter of the chamber sections on the testbed is $2.055 \mathrm{in}$. Oxygen and nitrogen were mixed to simulate air and a significant portion of the testing used oxygen enriched air. For the metallized gelled JP testing, the testbed was configured similarly to previous GRC JP detonation testing and similar to the configuration run at the Naval Postgraduate School (ref. 29). A bellmouth shaped head end mixer as well as a 12 in. Schelkin spiral obstacle geometry were used for most of the testing. 


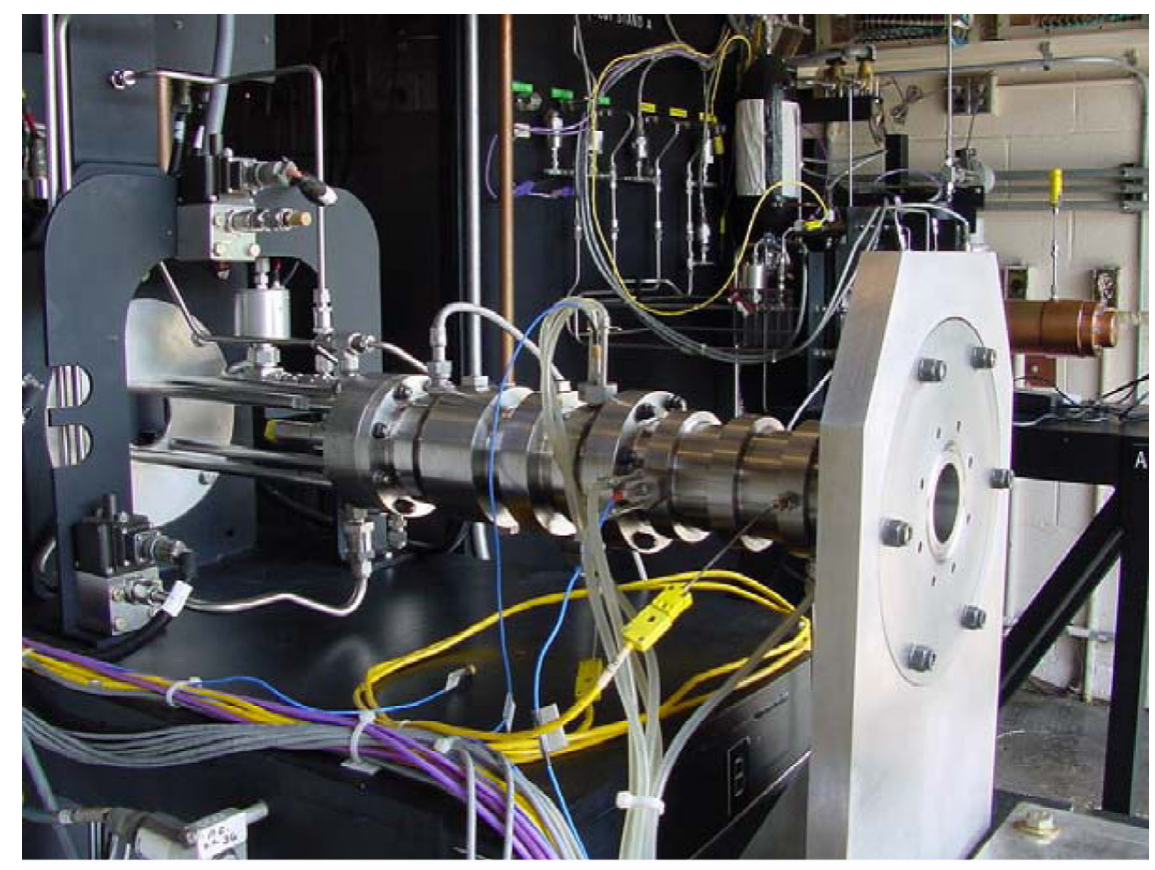

Figure 10.-PDE hardware setup (overall view).

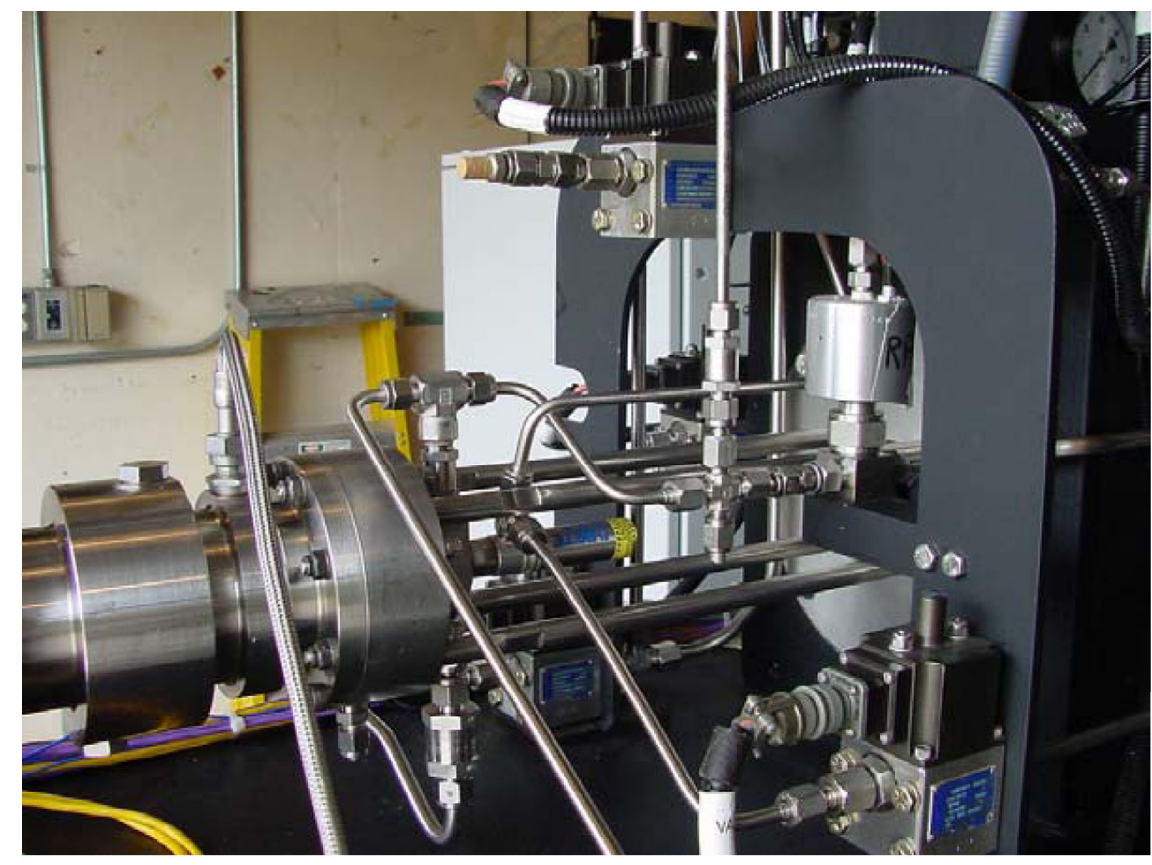

Figure 11._PDE hardware setup (injector end). 


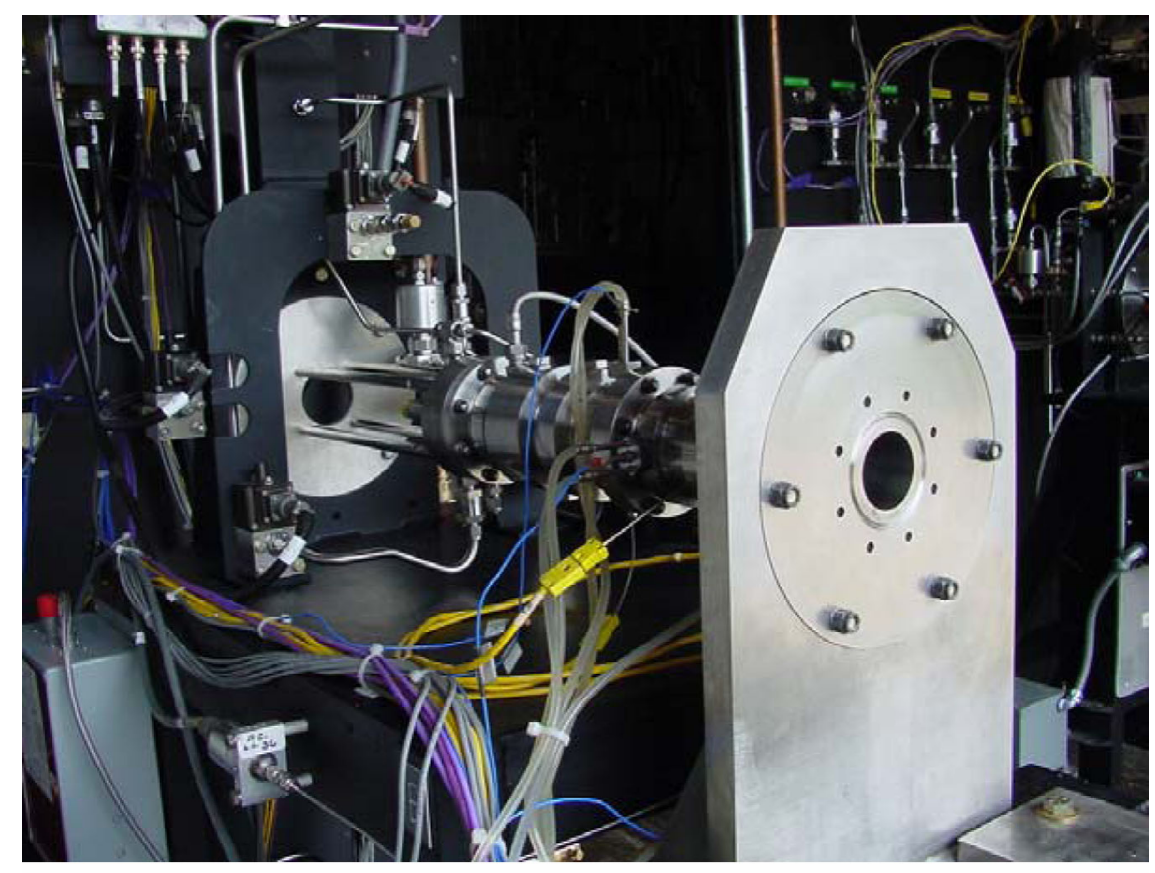

Figure 12.-PDE hardware setup (exit nozzle end).

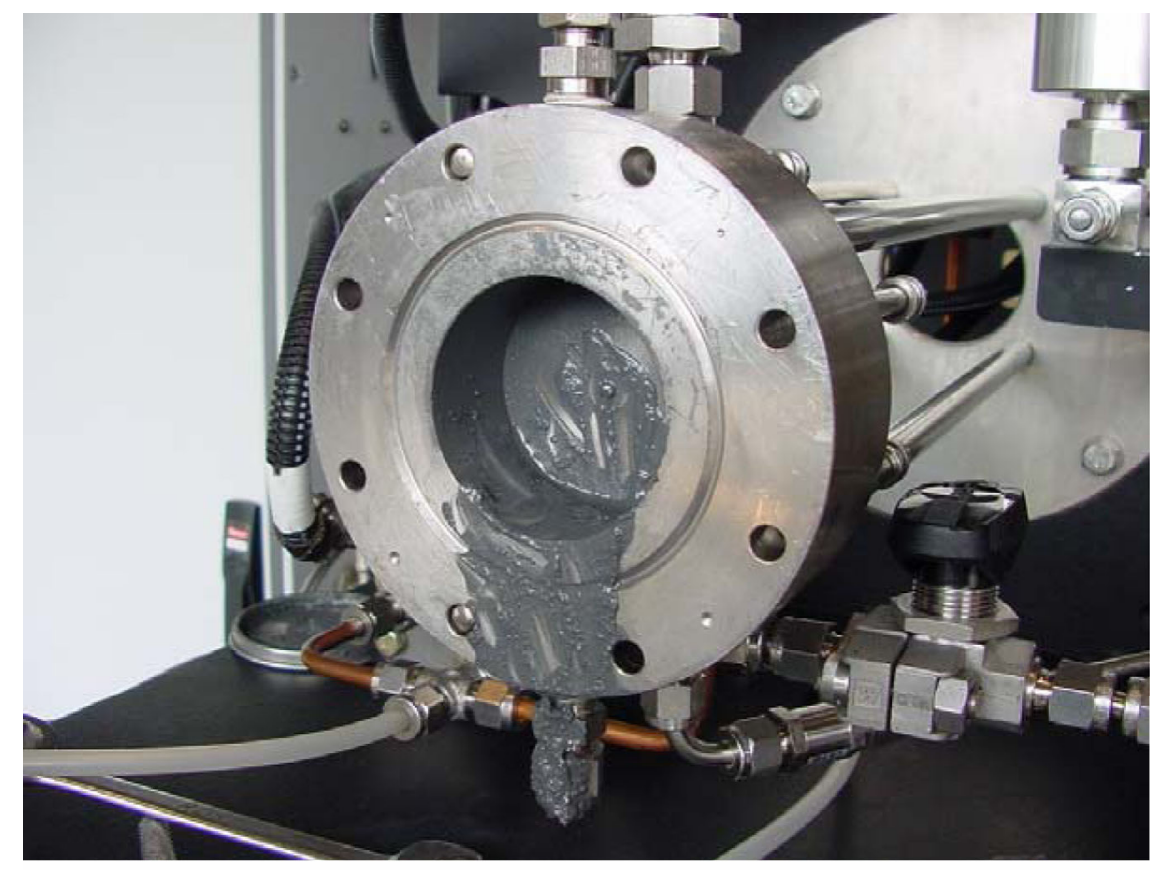

Figure 13.-Metallized gelled fuel injector cleanup after firing day completed. 
The major change for metallized fuel testing was the addition of a small high pressure positive displacement piston cylinder in the fuel system. The stroke of the cylinder provided a reliable and consistent slug of metallized fuel to be introduced to the combustor through the injector. The injector, shown in figure 11, was mounted at the head end of the device. The injector consisted of a BETE fog nozzle permanently affixed to a head end flange that was bolted to the rig. The fog nozzle has a central, pneumatically controlled pintle that meters the fuel and air flow. The pneumatics of the pintle were controlled by two high speed Flodyne valves. A Unison controller/exciter unit was used to control the timing of the high speed valves as well as the firing of the spark plug. A single wall mounted spark plug was used with a typical energy of $500 \mathrm{~mJ}$. The speed of transit of the combustion front was determined using an array of high speed pressure transducers located axially down the rig. The high speed pressure data was sampled and recorded at $900 \mathrm{KHz}$.

The use of a small high pressure positive displacement piston cylinder allowed effective and consistent flow of the metallized gelled fuel to the injector. As with previously performed rocket testing, after daily testing was completed, the fuel was evacuated from the feed system (ref. 15). Figure 13 shows the engine being cleaned at the end of a test day after a series of test runs. The engine proved reliable with the gelled fuel feed system.

\section{Data Interpretation}

Table II provides the overall test results for the metallized gelled JP-8/aluminum tests. Figure 14 shows the oxygen addition versus metal loading in the JP-8/aluminum fuel. The data are shown for a wide range of test conditions for the metallized gelled fuels. A general trend of reduced $\mathrm{O}_{2}$ for ignition is evident. The data show a trend of reducing $\mathrm{O}_{2}$ needed until reaching a metal loading of $12 \mathrm{wt} \%$ aluminum. Higher metal loadings then require larger amounts of added $\mathrm{O}_{2}$. The lowest required amount of $\mathrm{O}_{2}$ is $21-\mathrm{wt} \%$. This value is below that which is typical of the $23-\mathrm{wt} \% \mathrm{O}_{2}$ available in standard air. It should be noted that the velocity of detonation was achieved in only some of the test data points of figure 14 , and table II.

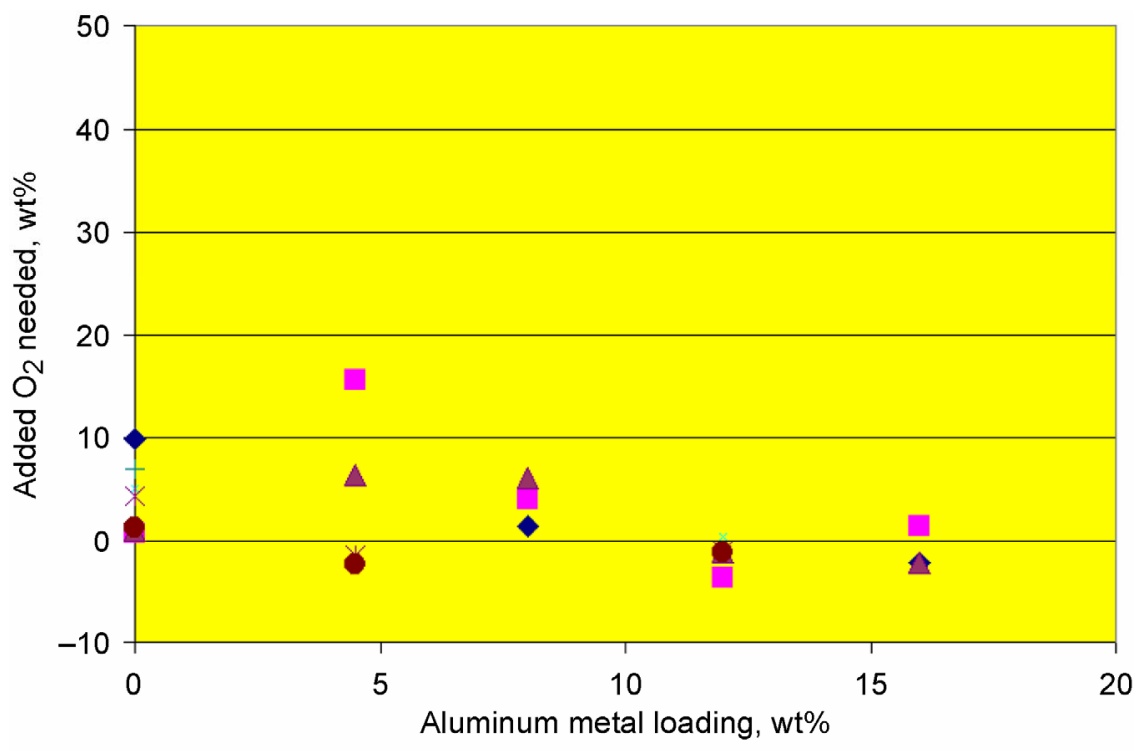

Figure 14. $-\mathrm{O}_{2}$ added versus JP-8/aluminum metal loading 
TABLE II.-PDE IGNITION TESTING WITH METALLIZED GELLED FUELS $\begin{array}{llll}\text { Run no. } \quad \mathrm{V} 23(\mathrm{~m} / \mathrm{s}) \quad \mathrm{V} 34(\mathrm{~m} / \mathrm{s}) \quad \mathrm{O} 2 \mathrm{wt} \% \quad \text { Fuel/Air ratio } & \begin{array}{l}\text { Pressure, } \\ \text { maximum } \\ \text { (psia) }\end{array}\end{array}$

JP-8 (0-wt\%, no metal)

$\begin{array}{cccccc}1255 & 1198 & 1051 & 34.8 & 0.117 & 360 \\ 1256 & & 64 & 25.6 & 0.036 & 72 \\ 1257 & & & 26 & 0.025 & 68 \\ 1258 & 873 & 849 & 30 & 0.0603 & 220 \\ 1259 & 647 & 1363 & 29.3 & 0.133 & 280 \\ 1260 & & & 26.3 & 0.161 & \\ 1261 & & & 31.9 & 0.068 & \end{array}$

JP-8 / Aluminum (4.85 wt\%)

$\begin{array}{llcccc}1264 & 1255 & 1349 & 83.4 & 0.198 & 700 \\ 1265 & 1116 & 1299 & 40.6 & 0.21 & 160 \\ 1266 & 1361 & 1721 & 31.4 & 0.36 & 938 \\ 1267 & & & 23.1 & 0.22 & 100 \\ 1268 & & 21 & 23.4 & 0.314 & 123 \\ 1269 & & 1084 & 22.6 & 0.24 & 145\end{array}$

JP-8 / Aluminum (8.0 wt\%)

112

113

772

26.4
29
31

0.113

0.085

0.128

JP-8 / Aluminum (12.0 wt\%)

1302

1303

1304

1305

1306

1307

1309

1310

1311

1318

1319

1321
1084

1606

1487

1487

892

622

1085

1100

902

1181

100
21.3
23.7
25.4
23.9
23.8
28.8
25
27.4

0.336

0.135

0.099

0.089

0.124

0.246

0.102

0.1207

0.0977

877

27.4

JP-8 / Aluminum (16.0 wt\%)

$\begin{array}{lccc}1565 & 22.3 & 0.1358 & 1020 \\ 1157 & 2.4 & 0.133 & 510 \\ 1252 & 22.8 & 0.099 & 1340\end{array}$

JP-8 / Aluminum (25.0 wt\%)

Weak detonations produced 


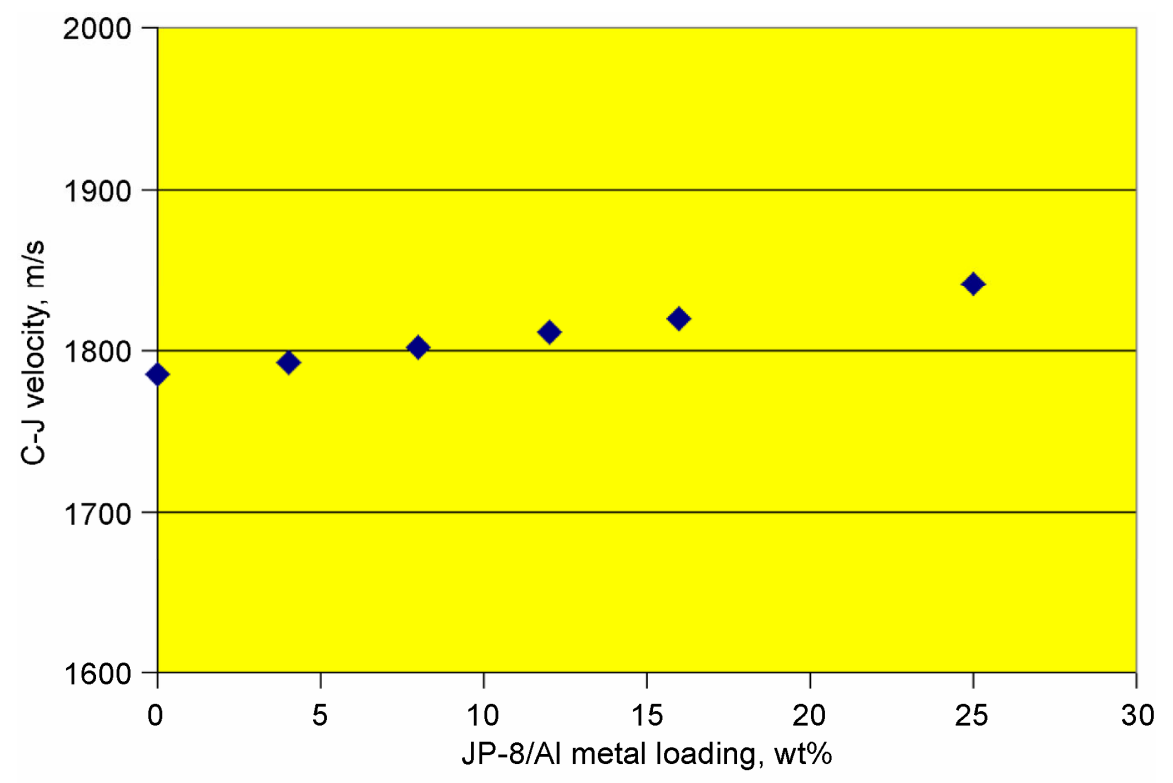

Figure 15.-C-J velocity versus JP-8/aluminum metal loading.

Figure 15 presents the C-J velocity for JP-8/aluminum metal loadings. Table III shows the theoretical, gas phase Chapman-Jouget (C-J) detonation velocities for various weight loadings of aluminum with Jet-A in the fuel. For a simulated air (23.2\% oxygen by weight) environment at atmospheric pressure and temperature, a monotonic increase in C-J velocity and burned to unburned gas pressure ratio occurs as the percentage of aluminum loading in the fuel increases. As expected, a significant rise in $\mathrm{C}-\mathrm{J}$ velocity and compression ratio occurs as the oxygen content of the air is increase at a given 16 percent metal loading. Due to the very small size of the nanoparticulate aluminum particles, a significant portion of the mass of the particle can be the aluminum oxide layer that forms on the exterior of the particle. The last row of table III shows the minimal effect on detonation parameters if a significant portion of the mass ( 37.5 percent) is composed of aluminum oxide.

TABLE III.-C-J VELOCITIES FOR PDE

\begin{tabular}{cccccccc}
\hline \multicolumn{6}{c}{ Oxidizer $\left(\mathrm{O}_{2}\right.$ and $\left.\mathrm{N}_{2}\right)$} & \multicolumn{2}{l}{ JP-8/Al fuel (to achieve Phi = 1) } \\
\hline $\begin{array}{c}\mathrm{O}_{2} \\
(\mathrm{wt} \%)\end{array}$ & $\begin{array}{c}\mathrm{N}_{2} \\
(\mathrm{wt} \%)\end{array}$ & $\begin{array}{c}\text { Percent fuel } \\
(\mathrm{wt} \%)\end{array}$ & $\mathrm{Phi}$ & $\begin{array}{c}\mathrm{Al} \\
(\mathrm{wt} \%)\end{array}$ & $\begin{array}{c}\mathrm{Al}_{2} \mathrm{O}_{3} \\
(\mathrm{wt} \%)\end{array}$ & $\mathrm{P} / \mathrm{Pi}$ & $\begin{array}{c}\text { C-J velocity } \\
(\mathrm{m} / \mathrm{s})\end{array}$ \\
\hline 23 & 77 & 6.34 & 1 & 0 & & 18.50 & 1785 \\
23 & 77 & 7.67 & 1 & 25 & & 19.90 & 1842 \\
23 & 77 & 7.13 & 1 & 16 & & 19.20 & 1820 \\
23 & 77 & 6.91 & 1 & 12 & & 19.00 & 1811 \\
23 & 77 & 6.71 & 1 & 8 & & 18.90 & 1802 \\
23 & 77 & 6.52 & 1 & 4 & & 18.70 & 1793 \\
& & & & & & 21.70 & 1906 \\
30 & 70 & 9.10 & 1 & 16 & & 27.20 & 2071 \\
50 & 50 & 12.30 & 1 & 16 & & 39.50 & 2324 \\
100 & 0 & 25.00 & 1 & 16 & & & \\
& & & & & & 39.80 & 2314 (effect of $\left.\mathrm{Al}_{2} \mathrm{O}_{3}\right)$ \\
\hline
\end{tabular}


There was some concern about being able to directly ignite these propellants without an auxiliary ignition source (i.e., a torch igniter). However, these concerns were unfounded. Ignition of the combustor was obtained with a direct spark source for all metal loadings of the fuel with the exception of the 25 percent metal loading. Ignition of this weight loading proved very difficult. Table II summarizes the tests that were conducted with metallized aluminum/JP-8 fuel on the CVCCE testbed. V23 and V34 are the combustion wave velocities measured using the time interval between pressure spikes between high speed pressure transducer 2 and 3 and 3 and 4 respectively. The maximum pressure is the highest pressure spike recorded on any of the high speed pressure transducers on the device. The pressure transducers were numbered 1 through 5 from the injector end to the exhaust end of the device. Several hot fire tests were conducted with neat JP-8 (no metal added) to confirm rig operation. These tests with neat $\mathrm{JP}-8$ also were used to verify what had been seen previously during liquid jet fuel detonation testing at GRC and elsewhere, that below an oxygen concentration of approximately 30 percent by weight, it was not possible to obtain detonations or rapid detonation like combustion. In this relatively short rig configuration (22 in.), full C-J velocities were not obtained even for the neat JP cases most likely due to a lack of length to fully transition to a detonation.

At metal loadings of 4.85 and 8 percent no appreciable decrease in the amount of oxygen enrichment necessary to obtain detonation like combustion is observed. Although the intended fuel/air ratio for these tests was stoichiometric or just on the rich side of stoichiometric, this was not always achieved due to the difficulty of metering these flows.

At a metal loading of 12 percent, combustion wave velocities 74 percent of the C-J velocity were measured at oxygen enrichment fractions below 30 percent. At a metal loading of 16 percent, combustion wave velocities 86 percent of the C-J velocity were obtained at oxygen enrichment fractions below 23 percent. Thus detonation like combustion was achieved at atmospheric temperature and pressure at oxygen fractions similar to those of standard air. A typical high speed pressure trace from one of these tests is shown in figure 16.

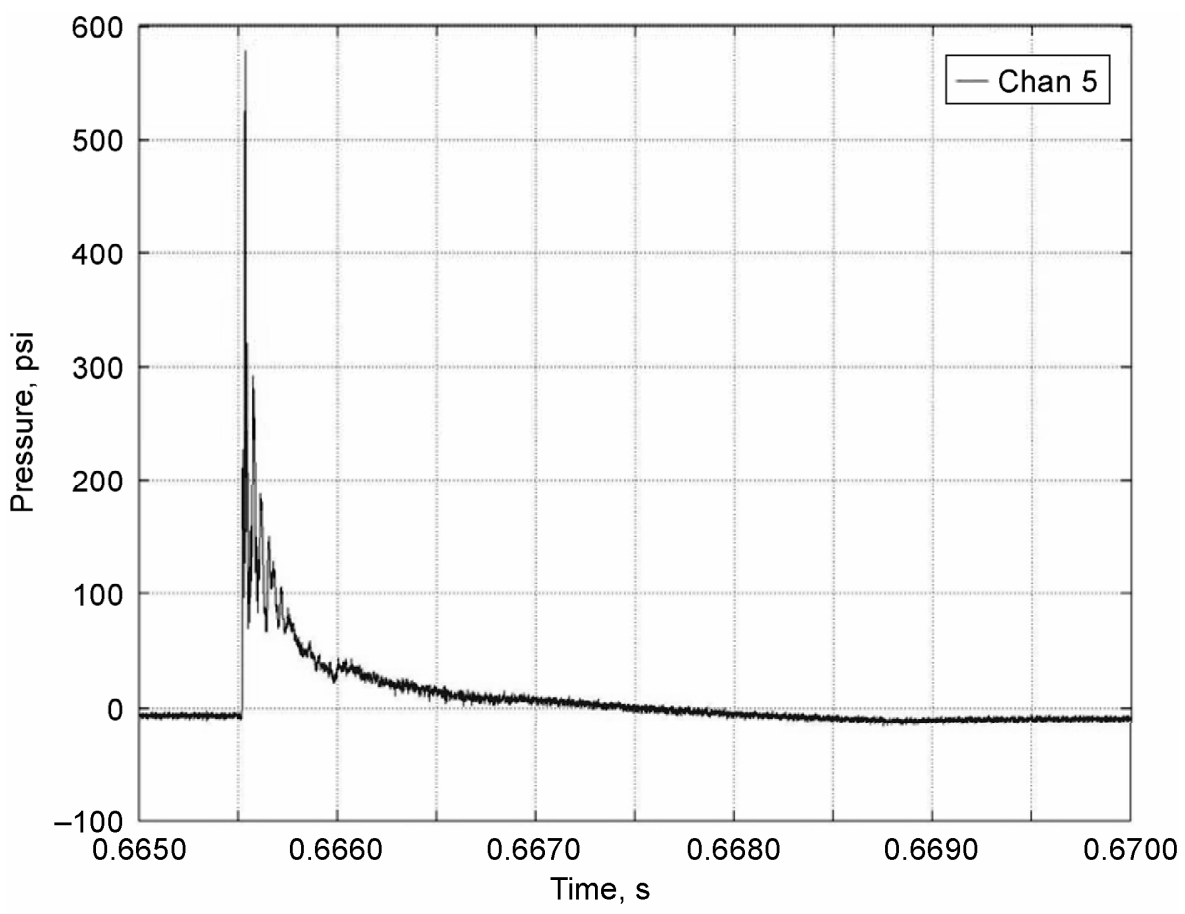

Figure 16.-Typical PDE pulse: pressure versus time. 


\section{Observations}

During testing, only single shot firings of the PDE were conducted with the metallized gelled fuel. Multiple shots were not planned as we wished to see if any improvements were possible with the gelled fuel. In many cases, improvements in the detonation velocity were observed. Further testing and analyses will be required to optimize the configuration of the PDE.

After the engine testing, the engine was partially disassembled, allowing us to clean any residual fuel in the PDE detonation tube and feed system. Images of a small amount of residual fuel are shown in figure 13. Also, at the end of the test day, residual fuel in the feed system was expelled. This expulsion prevents unwanted fuel drying when it is exposed to air (ref. 15). This feature is a prime part of the safety aspects of gelled fuels touted by the military services. Unwanted leakage would stop quickly, preventing any fratricide of other vehicles in the area.

\section{Concluding Remarks}

Metallized gelled fuels have many applications in aeronautics and space flight. While the applications of PDEs are in the future, testing should continue to reveal the best operating points for these engines. Increased metal loading testing would allow better packaging of the fuel in the missile or other aerospace vehicle. The combustion efficiency for the higher metal loadings has not yet been investigated, and is a good area for continued research. Improvements of the PDE with the use of a compressor section seem warranted.

\section{Conclusions}

A metallized gelled JP-8/aluminum fuel was created to be combusted in a pulse detonation engine. The fuel was formulated successfully with JP-8, nanometer sized aluminum particles, and nanoengineered gellants. Using a sonicator, the fuel was well mixed for the testing, and remained stable for the 1 to 2 week time span from formulation to engine firing. Metal loadings in the JP-8/aluminum were from 4.85 to $25 \mathrm{wt} \%$. Gellant amounts used were 1 to $2.4 \mathrm{wt} \%$

Using the JP-8/aluminum with nanometer-sized metal particles, the combustion in the PDE was achieved without added oxygen addition. A minimum metal loading of 12 to $18 \mathrm{wt} \%$ allowed the JP-8 aluminum combustion without oxygen addition. A PDE with metallized gelled fuels has the potential for reducing the dependence on added $\mathrm{O}_{2}$ for ignition and simplifying the engine design. Also, by increasing the fuel density the metallized gelled fuel can make the vehicle more compact. Metallized gelled propellants and propulsion can offer many vehicle advantages and create a bright future for many high energy aerospace visions.

\section{References}

1. Palaszewski, B., "Nanotechnology and Gelled Fuels for Aerospace Vehicles," presented at the Propulsion Engineering Research Center's 14th Annual Symposium on Propulsion, Pennsylvania State University, State College, PA, December 10-11, 2002.

2. Adams, S., Starkovich, J., and Palaszewski, B., "Nanoparticulate Gellants for Metallized Gelled Liquid Hydrogen with Aluminum," AIAA-96-3234, NASA TM-107280, presented at the 32nd AIAA/ASME/SAE Joint Propulsion Conference, Lake Buena Vista, FL, July 1996.

3. Wong, W., Starkovich, J., Adams, S., and Palaszewski, B., "Cryogenic Gellant and Fuel Formulation for Metallized Gelled Propellants: Hydrocarbons and Hydrogen with Aluminum," AIAA-94-3175, NASA TM-106698, presented at the 30th AIAA/ASME/SAE Joint Propulsion Conference, Indianapolis, IN , June 27-29, 1994.

4. Palaszewski, B., "Metallized Gelled Propellants: Historical and Future Developments," Invited Plenary Lecture, presented at the $8^{\text {th }}$ International Workshop on Combustion and Propulsion: Rocket 
Propulsion: Present and Future, Pozzuoli, Naples, Italy, 16-21 June 2002, Sponsored by: AIDAA, FiatAvio, Politecnico di Milano, Università di Napoli "Federico II"

5. Palaszewski, B., Ianovski, L., and Carrick, P., "Propellant Technologies: Far Reaching Benefits for Aeronautical and Space Vehicle Propulsion," in the Special Edition of the AIAA Journal of Propulsion and Power, September/October 1998, pp. 641-648.

6. Palaszewski, B., "Metallized Gelled Propellants: Oxygen /RP-1 /Aluminum Rocket Calorimeter Heat Transfer Measurements and Analysis," AIAA-97-2974, NASA TM-107495, presented at the 33rd AIAA/ASME/SAE Joint Propulsion Conference, Seattle, WA, July 1997.

7. Pelaccio, D., Palaszewski, B., and O'Leary, R., "Preliminary Assessment of Using Gel and Hybrid Propellant Propulsion for VTOL/SSTO Launch Systems," AIAA-97-3216, NASA TM 1998206306, presented at the 33rd AIAA/ASME/SAE Joint Propulsion Conference, Seattle, WA, July 1997.

8. Palaszewski, B. and Zakany, J., "Metallized Gelled Propellants: Oxygen/RP-1/Aluminum Rocket Heat Transfer and Combustion Experiments," AIAA-96-2622, NASA TM-107309, presented at the 32nd AIAA/ASME/SAE Joint Propulsion Conference, Lake Buena Vista, FL, July 1996.

9. Nieder, E., Harrod, C., Rodgers, F., Rapp, D., and Palaszewski, B., "Metallized Gelled Monopropellants," NASA TM-105418, April 1992.

10. Palaszewski, B. and Rapp, D., "Design Issues for Propulsion Systems Using Metallized Propellants," NASA Lewis Research Center, AIAA-91-3484, NASA TM-105190, presented at the AIAA/NASA/OAI Conference On Advanced SEI Technologies, Cleveland, OH, September 4-6, 1991.

11. Palaszewski, B. and Powell, R., "Launch Vehicle Propulsion Using Metallized Propellants," NASA Lewis Research Center, AIAA-91-2050, NASA TM-104456, presented at the 27th AIAA/ASME/SAE Joint Propulsion Conference, Sacramento, CA , June 24-27, 1991, also in AIAA Journal of Propulsion and Power, vol. 10, no. 6, Nov.-Dec. 1994, pp. 828-833.

12. Palaszewski, B., "Advanced Launch Vehicle Upper Stages Using Metallized Propellants," NASA Lewis Research Center, NASA TP-3191, NASA TM-103622, presented at the JANNAF Propulsion Meeting, Anaheim, CA, October 3-5, 1990.

13. Palaszewski, B., "Lunar Missions Using Advanced Chemical Propulsion: System Design Issues," NASA Lewis Research Center, NASA TP-3065, AIAA-90-2341, presented at the 26th AIAA/ASME/SAE Joint Propulsion Conference, Orlando, FL, July, 1990, also in AIAA Journal of Spacecraft and Rockets, vol. 31, no. 3, May-June 1994, pp. 458-465.

14. Palaszewski, B., "Metallized Propellants for the Human Exploration of Mars ," NASA Lewis Research Center, NASA TP-3062, presented at the Case For Mars IV Conference, Boulder, CO, June 4-8 1990. Also in the AIAA Journal of Propulsion and Power, vol. 8, no. 6, Nov.-Dec. 1992, pp. 1192-1199.

15. Palaszewski, B., "Metallized Gelled Propellant Experiences and Lessons Learned: Oxygen /RP-1 /Aluminum Rocket Engine Testing," presented at the JANNAF Gel Propulsion Technology Symposium, Huntsville, AL, September 1995.

16. Palaszewski, B. and Zakany, J., "Metallized Gelled Propellants: Oxygen /RP-1 /Aluminum Rocket Combustion Experiments," AIAA-95-2435, NASA TM-107025, presented at the 31st AIAA/ASME/SAE Joint Propulsion Conference, San Diego, CA, July 1995.

17. Anon., "The Army Looks to the Future With Variable Thrust Propulsion," Chemical Propulsion Information Agency Bulletin, The Johns Hopkins University, vol. 27, no. 1, January 2001. http://www.cpia.jhu.edu/Bulletin/PDFFiles/jan01bulletin.pdf

18. "Review of NASA's Aerospace Technology Enterprise: An Assessment of NASA's Aeronautics Technology Programs," Committee for the Review of NASA's Revolutionize Aviation Program, Aeronautics and Space Engineering Board, Division on Engineering and Physical Sciences, National Academies Press, Washington, DC, 2004

19. Povinelli, L., "Dissociation and Recombination Effects on the Performance of Pulse Detonation Engines,” NASA/TM-2003-212538, ISABE-2003-1216, August 2003, 
20. Louis A. Povinelli and Jin-Ho Lee, Michael O. Anderberg, "Role of Air-Breathing Pulse Detonation Engines in High Speed Propulsion," IAF-01-S.5.01, NASA/TM-2001-211163, September 2001

21. Whitlow, W. Jr., Blech, R., and Blankson, I., "Innovative Airbreathing Propulsion Concepts for Access to Space," NASA/TM-2001-210564, October 2001.

22. NASA Glenn Aero Base program web site: http://www.grc.nasa.gov/WWW/AERO/base/pdet.htm

23. Perkins, H. D., "Effects of Fuel Distribution on Detonation Tube Performance," NASA/TM-2002211712, August 2002.

24. Paxson, D. E., "A Performance Map for Ideal Air Breathing Pulse Detonation Engines," NASA/TM-2001-211085, AIAA-2001-3465, July 2001.

25. Robert J. Santoro and Sibtosh Pal, "Thrust Augmentation Measurements Using a Pulse Detonation Engine Ejector," Pennsylvania State University, Propulsion Engineering Research Center and Department of Mechanical and Nuclear Engineering, NASA/CR -2003-212191, NAG3-2657, March 2003

26. R.J. Pegg, B.D. Couch and L.G. Hunter, Pulse Detonation Engine Air Induction System Analysis, 32nd AIAA/ASME/SAE/ASEE Joint Propulsion Conference and Exhibit, Lake Buena Vista, FL, AIAA Paper No. 96-2918, July 1-3, 1996.

27. Vehicle Systems Overview: CVCCE work: http://www.asdl.gatech.edu/teams/ureti/ AnnualReview2003/02UAPTSeng092403.pdf

28. Perkins, Hugh Douglas, "Effects of Fuel Distribution on Detonation Tube Performance," NASA/TM-2002-211712, August 2002. (PDE cycle numbers)

29. C.M. Brophy, J.O. Sinibaldi, D.W. Netzer, and R.G. Johnson, "Operation of a JP-10 /Air Pulse Detonation Engine," 36th AIAA/ASME/SAE/ASEE Joint Propulsion Conference, Huntsville, AL. AIAA Paper 2000-3591, July 2000.

30. LANL web site-Nanoscience and Technology: nanoparticles of aluminum: http://www.lanl.gov/mst/nano/docs/alpowder.pdf

31. "Detail Specification, Turbine Fuels, Aviation, Kerosene Types, NATO F-34 (JP-8), NATO F-35, AND JP-8+100," MIL-DTL-83133E, 1 April 1999, Superseding MIL-T-83133D, 29 January1992. http://www.desc.dla.mil/DCM/Files/t83133e.pdf

32. Nanotechnologies, Austin,Texas: www.nanoscale.com. and merger of Technanogy and Nanotechnologies: http://www.nanoscale.com/pdfs/technanogy.pdf

33. NASA Glenn Transmission electron microscopy (TEM) description: http://www.grc.nasa.gov/ WWW/AdvMet/ASGWEB2000/asghome.html

34. Wong, S.C. and Turns, S.R. "Ignition of Aluminum Slurry. Droplets," Combustion Science and Technology, vol. 52, pp. 222-242, 1987.

35. Mueller, D.C. and S.R. Turns. "Some Aspects of Secondary Atomization of Aluminum/Hydrocarbon Slurry Propellants." Journal of Propulsion and Power vol. 9, no. 3, pp. 345-351, 1993.

36. Kearns, K., "The Revamping of an Ignition Test Facility," NASA/TM-2002-212095, AIAA-20037362, December 2002.

37. Bonnie J. McBride and Sanford Gordon, "Computer Program for Calculation of Complex Chemical Equilibrium Compositions and Applications II (CEA). User's Manual and Program Description,” NASA RP-1311-P2, June 1996. 


\section{Appendix A}

JP-8 Density (Military Specification) and Metallized Gelled Fuel Densities

JP-8 Density $\left(\mathrm{kg} / \mathrm{m}^{3}\right)=775$ (minimum) to 840 (maximum)

Density $=1 /((1-\mathrm{ML} / 100) /$ density, liquid $+\mathrm{ML} / 100 /$ density, metal $)$

Density increase $=\{[$ Density $(@ w t \%)-$ Density $($ no metal $)] /$ Density $($ no metal $)\} * 100$

$\begin{array}{ccccc}\begin{array}{c}\text { Al in fuel } \\ \text { (ML, wt\%) }\end{array} & \begin{array}{c}\text { Density of metallized gelled JP-8/Al } \\ \text { JP-8/Al density } \\ \left(\mathrm{kg} / \mathrm{m}^{3}, \text { min. }\right)\end{array} & \begin{array}{c}\text { Density increase } \\ (\%, \text { min. })\end{array} & \begin{array}{c}\mathrm{JP}-8 / \mathrm{Al} \text { density } \\ \left(\mathrm{kg} / \mathrm{m}^{3}, \text { max. }\right)\end{array} & \begin{array}{c}\text { Density increase } \\ (\%, \text { max. })\end{array} \\ 0.00 & 775.00 & 0.00 & 840.00 & 0.00 \\ 4.85 & 802.76 & 3.58 & 869.04 & 3.46 \\ 8.00 & 821.88 & 6.05 & 888.99 & 5.83 \\ 12.00 & 847.51 & 9.36 & 915.70 & 9.01 \\ 16.00 & 874.79 & 12.88 & 944.06 & 12.39 \\ 25.00 & 943.10 & 21.69 & 1014.77 & 20.81 \\ 30.00 & 985.87 & 27.21 & 1058.82 & 26.05 \\ 40.00 & 1084.20 & 39.90 & 1159.51 & 38.04 \\ 50.00 & 1204.32 & 55.40 & 1281.36 & 52.54 \\ 60.00 & 1354.37 & 74.76 & 1431.82 & 70.45 \\ 70.00 & 1547.13 & 99.63 & 1622.32 & 93.13\end{array}$






\section{SUPPLEMENTARY NOTES}

Prepared for the 40th Joint Propulsion Conference and Exhibit cosponsored by AIAA, ASME, SAE, and ASEE, Fort Lauderdale, Florida, July 11-14, 2004. Bryan Palaszewski, Kevin Breisacher, and Kim Kearns, NASA Glenn Research Center; John Jurns, QSS Group, Inc., 21000 Brookpark Road, Cleveland, Ohio. Responsible person, Bryan Palaszewski, organization code RTB, 216-977-7493, e-mail: bryan.a.palaszewski@nasa.gov.

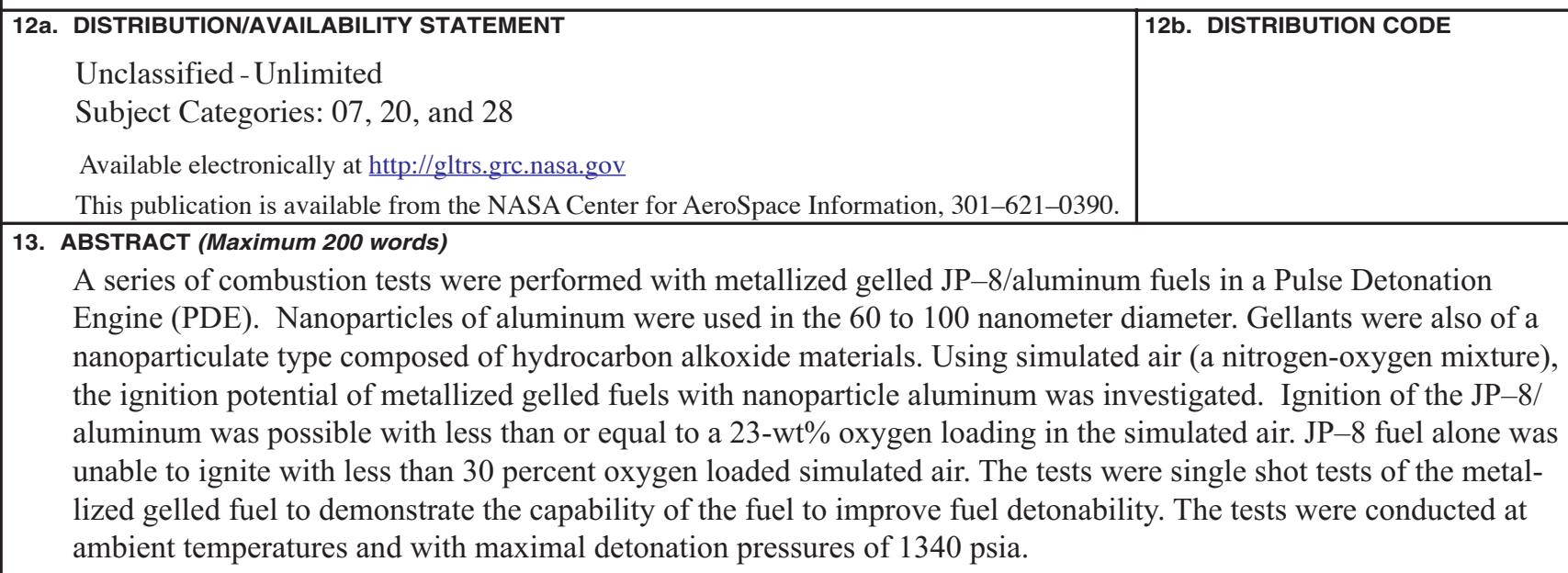

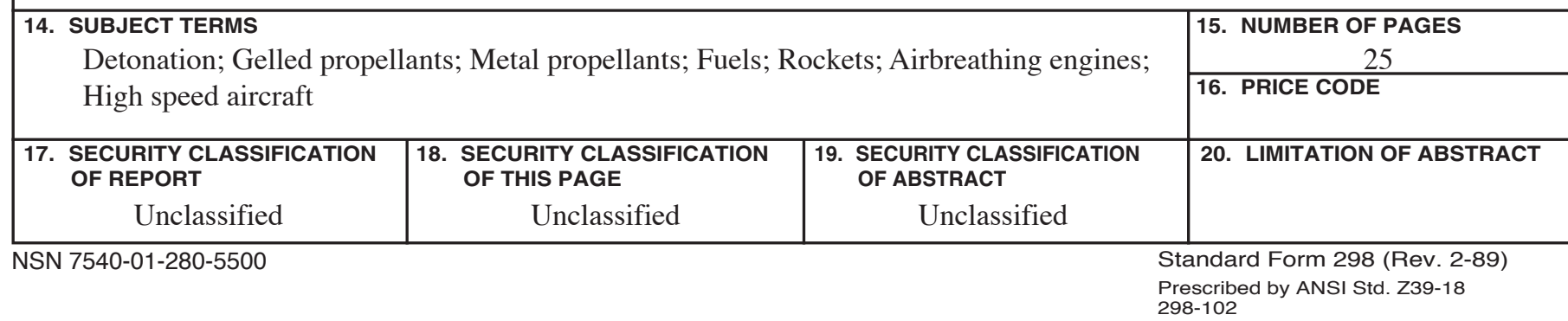



